\title{
Village Community Business in Maintaining Traditional Food "Opak Ladu" Based in Creative Economics
}

\author{
Beni Dwi Komara*, Laily Maghfiroh, Heri Cahyo Bagus Setiawan and Aries \\ Kurniawan
}

Study Program of Entrepreneurship, Economy and Business Faculty, Muhammadiyah of University, Gresik

*Corresponding author email: benikomara@umg.ac.id

\begin{abstract}
This study aims to determine the existence of traditional Opak Ladu food in society, the development of producers, and the efforts made to maintain based on a creative economy so that it is able to be a solution to the problems of economic inequality and welfare. This study used descriptive research with a qualitative approach in order to be able to reveal systematically, factually, and accurately the facts and characteristics of the research object. The results of this study indicate that the people of Lamongan still hold a hereditary tradition of serving Opak Ladu as a special dish on Idul Fitri so that sales increase almost 10 times, but on weekdays the demand is very small because consumers are the older generation only while the younger generation has more fast food. serving. This small demand resulted in a decrease in the number of producers, only 6 of whom were old. The younger generation are reluctant to become producers and prefer to migrate to look for work. The community and local government have conducted entrepreneurship training efforts for producers and housewives, and the village government has included the products at various product exhibitions, but the results have not been able to increase demand. Suggestions In the future, it is necessary to optimize real steps for the creative economy in the form of updating innovative marketing strategies, creating mutual product identities, approaching product communication through product displays \& Digital Marketing, and establishing cooperation with business stake holders.
\end{abstract}

Keywords: Community Business, Traditional Food, Opak Ladu

\section{INTRODUCTION}

Era of the industrial revolution 4.0 makes the creative economy one of the strategic issues that deserves to be the main strategy to win global competition, the key is to continue to innovate and be creative in order to increase economic added value through the capitalization of creative ideas. The fact was conveyed by Howkins that in America there has been a new economic wave in the form of creativity-based goods and services with a value of more than USD 414 billion in 2017 alone. Defines it as an economic activity that rests on the exploration and exploitation of creative ideas that have high selling value. There are 16 sectors, including fashion, art, culinary, product design, online games, films, animation, and others, which are worthy of being a strategic choice to continue to be developed. The phenomenon of the Burger King Franchise, Yoshinoya and Susie food, the traditional food of a country that spreads throughout the world, is just an example of how creativity can become a new economic engine [1].

This phenomenon reminds us of Indonesia which is rich in culture and customs. One that is included in the cultural section is a variety of traditional foods (regional specialties). This is a great asset to create innovation and creativity in the goods and services we have [2]. The uniqueness of culture, arts, culinary, and handicrafts as well as the active role of Indonesian young entrepreneurs in developing various business startups can be a huge competitive advantage if managed seriously will be able to solve the problems of economic inequality and welfare [3].

Especially the culinary business has considerable potential, due to the increase in the souvenir business, according to a report by the Industry and Trade Service by 20-25 percent, much higher than the increase in economic growth which is only around 3 percent. Therefore, economists are optimistic that in the coming years, hawker centers will be brighter. Now it has grown rapidly and has even become one of the mainstays of the local government in increasing Regional Budget Revenue (PAD) [4]

This great culinary potential is also owned by the city of Lamongan. 2 things that Lamongan has, namely its natural beauty and strategic location make this city has culinary potential that can be developed into a tremendous economic power. Natural beauty has been managed to become a vehicle for tourism, including: Lamongan Marine Tourism (WBL), Maharani Cave and Tanjung Kodok Beach Resort. While the strategic location of Lamongan is on the arterial route of the north coast of Jakarta, Semarang, 
Surabaya, Bali, making it one of the busy routes and is visited by many people every day. During tourist visits and business routes, it is not complete without tasting the culinary and souvenirs of the city of Lamongan. Various types of food products that have been popular, such as "Soto Lamongan", "Nasi Boran", "Mixed Tofu" and various kinds of seafood dishes typical of Lamongan City have become the culinary icon of Lamongan City. The souvenir center contains many specialties from various regions. It is necessary to optimize the typical Lamongan food by packaging it attractively. So that in the future, it can optimally raise the image of Lamongan City as a culinary tourism destination.

Culinary potentials that need to be developed which originate from lamongan include Ladu opak. Soft texture, sweet and savory taste when bitten and has a variety of distinctive colors. At first glance, the shape is similar to the amplang crackers from South Kalimantan. For the people of Lamongan, this traditional food is a mandatory treat on Eid al-Fitr. The process of making ladu is still very traditional, starting with soaking the glutinous rice for 1 night then draining it first until it is dry then cooking it when it is cooked then pouring it in and mash until it is smooth then waiting to cool to mix the sugar then immediately pulled and dried for 4 hours then turned over and heated again for 2 hours then removed then let stand for 1 day then fried using sea sand. If only the weather was not dry, the producers chose not to make it because even if it was roasted the results would not be perfect. There is something unique about dicadu, namely when ladu is Javanese in "calm", then the ladu does not need to be thrown away or fried again, but it is enough to dry it over the sun so that it will be crispy again.

Opak Ladu is actually a typical food from the Prijekngablak village which has been producing it from generation to generation. However, there are only a few producers of Opak Ladu and all of them are old people. The consumers of this Ladu opak are also mostly from the older generation. Community efforts need to be made so that OpakLadu can be maintained and developed based on the creative economy so that it is able to be a solution to the problems of economic inequality and welfare.

This study aims to determine the existence of traditional Opak Ladu food in society, the development of Opak Ladu producers, and the efforts made to maintain Opak Ladu based on a creative economy so that it is able to be a solution to the problems of economic inequality and welfare.

\section{RESEARCH METHOD}

This study uses a descriptive method using qualitative analysis through analysis using a scientific approach in accordance with the actual situation. the sample is called the informant, namely the person who is the source of the information. Determining the subjects in this study, researchers used Porposeful Sampling, which is based on the characteristics of the selected subjects because these characteristics are in accordance with the objectives of the research to be carried out [5]. Based on the considerations, the informants in this study were:

- Head of Village

- Head of PKK / family welfare empowerment group \& 2 member.

- 6 Producers of Opak Ladu

The data used in this qualitative research are primary data and secondary data obtained from various sources. Primary or primary data is data of 10 people involved in the management of traditional food in Prijek Ngablak Village. Secondary data were collected by researchers to support primary data. This study uses the researcher himself as a research instrument. In this study, researchers collected information about the data needed by asking, asking, listening, and taking. Researchers collect these data themselves from various sources related to their research.

The data collection technique was carried out by means of field observations, interviews with informants, and documentation of research results to obtain materials and notes in accordance with the research theory.

\subsection{Research Technic}

This qualitative research uses a variety of sources, conducted in several locations in the city of Madiun using interview techniques, observation and strengthened documentation. Data collection was carried out continuously until it was complete to obtain high data validation. The snowball sampling technique is used, where data collection will be stopped if the data obtained is saturated. The data collected is generally in quantitative form, although it does not rule out some qualitative data being obtained. Meanwhile, data processing has been carried out before entering the field, during the field process and after finishing the field. This means that data processing has been started since the researcher formulated the problem until the researcher writes the results of the study. While the focus of data processing in the qualitative research model lies in the field when data collection. 


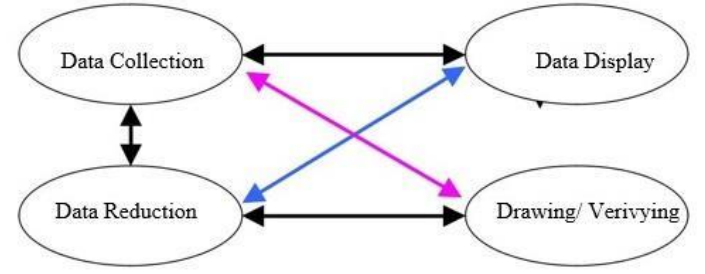

FIGURE 1. Data Processing Interactive Model Miles and Hubermann

\subsection{Data Analysis Techniques}

Analysis used interpretive descriptive supported by Miles and Huberman's theory [6]. The purpose of data analysis is to narrow the data and limit the findings to organized, structured and meaningful data. As for the purposes of analyzing data that has been collected, analysis techniques are needed in accordance with the types of data available, including:

- Validity, in measuring validity refers to the content and usefulness of measuring instruments, internal validity and external validity. As for what is meant by internal validity is how far a measuring instrument is able to describe the object to be measured. External validity is in relation to measuring instruments in different situations.

- Reliability, in determining this reliability, several things can be made standard, namely:

a) Accuracy or accuracy, which can contribute to a complete understanding of the object being measured.

b) Stability, that is, if the measurement is replicated, it will give the same results, but with due regard to the conditions when the measurement is relatively no different.

c) Homogeneity, where there is a close relationship between one another.

Meanwhile, to achieve a success in this qualitative research, it is necessary to pay attention to several things:

- Conducted in conditions as natural or natural as possible.

- Treat the person acting as an informant humanely and upholds the perspective for participation.
- The research results are discussed descriptively and synthetically.

- The deficiencies in the research will be addressed in a transparent manner [7]. Furthermore, in this data processing, the data analysis process is good.

\section{RESEARCH RESULTS AND DISCUSSION}

\subsection{The existence of "Opak Ladu" in the community}

Lamongan people still holds a hereditary tradition of presenting Opak Ladu as a special dish on Eid alFitr. This is in accordance with what was conveyed by Wati 62 years old, the producer of Ladu opak, "Ladu is actually the original dish of the Prijekngablak village which has been passed down from generation to generation, ladu itself is produced by a small proportion of residents here, almost all of whom are parents. Ladu is usually marketed in traditional markets such as the Pahing Friday market, the Sekaran market and the markets adjacent to this village. From there then spread to Lamongan. Wati, 64 year old Mrs. Kartini stated, "Lebaran has lots of Ladu orders. During Eid I can produce $120 \mathrm{~kg}$ per month or about $4 \mathrm{~kg}$ per day. On weekdays, the order might only be $4 \mathrm{~kg}$ a month. ". Opak Ladu's orders on Eid al-Fitr so that sales increase by $95 \%$, but on weekdays the demand is very small because consumers are only the older generation while the younger generation prefers fast food. This is also conveyed by Katiseh 65 years old, "Ladu buyers are mostly parents, most buyers are from outside villages such as Drajat, Laren, Blimbing, Sekaran, Peangean, Keduyung, Deket, Sungelebak even Ladu products are well known in northern Gresik, namely pan. they are happy to be complained because it is food since they were small For Eid there is no Ladu, it is less marem. But on normal days it is quiet, teenagers now don't know Ladu, they just know the current food. ". The minor problem with Opak Ladu's request on weekdays was also complained by 62-year-old Wati, "If orders every day are like Eid, that's good, but not so real. The problem is now. How are young people interested in buying Opak Ladu warsan ancestors who are actually no less delicious than the current model food? ". More over most of the ancestors of the Prijekngablak community understood and knew how to make ladu. But lately, these skills have not been mastered by young people in the village [8]. 


\subsection{The development of Opak Ladu producers}

The small demand resulted in a decrease in the number of Opak Ladu producers, only 6 of whom are old. The younger generation are reluctant to become Opak Ladu producers and prefer to migrate to look for work.This right is conveyed by 60 years old $\mathrm{Bu}$ Saminah, the head of PKK in Prijekngablak village, "In the past, most of the Prijekngablak's ancestors understood and knew how to make ladu. But lately, these skills have not been mastered by young people, many of them have migrated outside the village looking for work. ".Another obstacle is the lack of Ladu producers and manual mash equipment which makes the manufacturing process long and productivity small. As explained by the Head of Prijekngablak Village, Ali Ajib Anamsari, "The village government is very eager to preserve these snacks from their ancestors. However, we admit that the ladu production process is very constrained by manual method, so the production is slow. Moreover, the minimum amount of production and the lack of residents who are engaged in making ladu snacks, have resulted in the marketing of ladu snacks only serving consumers in the Lamongan area. Even though many requests come from outside Lamongan.In this case, it is very ironic, Ladu producers do not get certain orders on weekdays, making it impossible to grow new producers. On the other hand, there is a potential need for Opak Ladu to serve Lamongan and other cities due to product availability. In this case Local governments must act quickly by doing "Traditional food producer Reconstruction ". A policy that was oriented to the economy of the people to revive traditional markets and allow traditional traders to resell. Don't treat people only become social objects! Economy, politics of politicians and regional governments [9].

\subsection{The Community efforts to maintain}

\section{Opak Ladu based on a creative economy}

The community and local government have conducted entrepreneurship training efforts by providing knowledge, skills and business mentality to Opak Ladu producers and housewives. As expressed by 60-year-old BU Saminah, "Here entrepreneurship training is often carried out in collaboration with universities that are often KKN here. Not only creating Ladu, PKK mothers also learned what entrepreneurship is, skills in entrepreneurship and were told about the mentality of entrepreneurs. ". The village government also has an agenda to include these Opak Ladu products in various product exhibitions organized by the
Lamongan Regional Government and the East Java Provincial Government, according to the Prijekngablak Village Head, Ali Ajib Anamsari, "The village government has presented this Opak Ladu several times at exhibitions. Many like Prijekngaplak's Ladu. "

However, these efforts have not significantly increased Opak Ladu's demand on weekdays, as stated by Mrs. Kartini, "I have been selling ladu h from generation to generation from my grandmother for almost 10 years. But I only sell it for Eid. Because yes, it's only busy during Eid, if it's like this weekdays most of the people don't get messages". This situation need to involve creative economy using local wisdom. The era of globalization has pushed the global economy to all corners of the world. Therefore, the strength of the competitiveness of MSME products can be pursued by strengthening their local culture. The value of local wisdom can be a strength in increasing the competitiveness of MSME products towards exports [10].

\section{CONCLUSION}

The community's efforts to maintain Opak Ladu food in the village are as follows:

- The Lamongan community still holds a hereditary tradition of serving Opak Ladu as a special dish on Eid al-Fitr so that sales increase by 10 times, but on weekdays the demand is very high. small because the consumers of the older generation only while the younger generation prefer fast food.

- This small demand resulted in a decrease in the number of Opak Ladu producers, only 6 of whom were old. The younger generation are reluctant to become Opak Ladu producers and prefer to migrate to look for work.

- The community and local government have carried out entrepreneurship training efforts by providing knowledge, skills and business mentality to Opak Ladu producers and housewives, as well as including Opak Ladu products in various product exhibitions organized by the Lamongan and East Java Provincial Governments, but the results has not been able to increase Opak Ladu's demand.

\section{ACKNOWLEDGMENTS}

The authors would like to thank the Universitas Muhammadiyah Gresik for 
their financial support and the completion of this research.

\section{REFERENCES}

[1] "owkins, J, 2001. The Creative Economy: How people... - Google Cendekia." .

[2] D. (UIN A.-R. B. A. Hardianti, "Gutel Gayo, Upaya Masyarakat Kecamatan... - Google Cendekia," 2019. .

[3] E. C. H. K. ) Sugiarto, "Indonesia's Future Creative Economy," 2018. .

[4] A. Nasihuddin, "PUSAT WISATA KULINER DI KABUPATEN," 2010.

[5] H. Nassaji, "Qualitative and descriptive research: Data type versus data analysis," Language Teaching Research, vol. 19, no. 2. SAGE Publications Ltd, pp. 129-132, Mar. 2015, doi: 10.1177/1362168815572747.

[6] M. Miles, A. Huberman, and J. Saldaña, "Qualitative data analysis: A methods sourcebook," 2018.

[7] "Soerjono Soekanto., (1987) Pengantar Sosiologi... - Google Cendekia." .

[8] A. I. Arso, "Ladu, Jajanan Ramadhan Asli Prijekngablak Lamongan,” 2018. .

[9] B. D. Komara and A. Prasetya, "Konstruksi Sosial pada Pedagang Tradisional dalam Menghadapi Era Kompetisi Perdagangan Bebas," J. Ris. Entrep., 2019, doi: 10.30587/jre.v2i1.789.

[10] S. (Universitas P. J. Samodro, “"Upaya Meningkatkan Daya Saing... - Google Cendekia," 2018. . 